\title{
Haemocytic periodicity and periodic disorders: Periodic neutropenia, thrombocytopenia, lymphocytosis and anaemia
}

\author{
Hobart A. ReimanN \\ M.D. \\ The Department of Medicine, Hahnemann Medical College and Hospital, \\ Philadelphia, Pennsylvania 19102
}

\section{Summary}

Evidence has accumulated of rhythmic numerical oscillation of each of the blood cells either independently or in combinations.

The cyclic changes originate in the marrow of some normal persons and animals without causing illness, and can be induced experimentally.

In more than 100 reported instances, periodic oscillations of various cells were accompanied by respective episodes of the disorders named in the title. The disorders may be transitory but usually recur throughout life and occasionally are fatal. All resist therapy. Features in common suggest an interrelationship of the haemal disorders and other disparate heritable periodic diseases.

Theoretically, the rhythms are regulated by ubiquitous, inherent, intracellular bioclocks controlled hypothalamically or neurohumorally in relation to a feedback mechanism. Reactions to long cycles are of greater clinical importance than disturbances arising from the circadian rhythm.

\section{Introduction}

After the establishment of periodic (cyclic) neutropenia as an entity in 1949 (Reimann \& De Berardinis, 1949) nearly fifty cases were added to the forty-two cited in 1963 (Reimann, 1963). Because the trouble originates in the marrow, the term periodic myelodysplasia was proposed. The broad term applies if the numbers of more than one kind of haemocyte oscillate synchronously or independently as they often do. When neutrophils, platelets, monocytes, lymphocytes and erythrocytes alone oscillate, specific designation is appropriate. By including periodic disorders related to the numeric fluctuation of various haemocytes, the total number of reported cases involving the blood exceeds 100. Many unrecognized ones, no doubt, exist.

Periodic haemocytic changes are either primary or are associated with mensis, lymphomas and immunosuppressive therapy. In both circumstances, the involvement is either overt or clinically inapparent except for the numeric cellular oscillation. Periodicity escapes detection unless cells are counted at short intervals in patients, in healthy genetic relatives or others. Serial counts have disclosed periodicity in some patients regarded as cases of continuous, congenital or hereditary neutropenia (Morley, Carew \& Baikie, 1967).

Periodic neutropenia is heritable. Probably thrombocytopenia, lymphocytopenia and anaemia also are genetically transmissible. The disorders are nod always benign. Concurrent infection or bleeding occasionally is fatal. Therapy generally is ineffectualo the symptoms alone are meliorated, cellular cycles usually persist. This review stresses the periodicity of various haemocytes, their interrelated disorders and frequent heritability as described in published cases and personally observed ones. Articles cited in references recount detailed clinical features.

\section{Periodic neutropenia}

\section{Heredity}

Morley's studies, particularly his opportunity to study five afflicted families, provided much information. Twenty members had had overt disease, usually since infancy. Neutrophils also fluctuated rhythmically in several symptomless members. Some of them had continuous neutropenia with cycles of further depression. The tempo ranged from 15 to 35 days, averaging 20 . Synchronous monocytosis and fever occurred often. Anaemia, eosinophilia and thrombocytopenia concurred episodically in three relatives. An autosomal dominant trait of high penetrance and variable manifestations characterized the afflicted families (Morley et al., 1967).

Table 1 portrays thirty-seven primary cases accruing after forty-two previously recorded ones and includes a few I omitted in 1963. Table 2 shows $\stackrel{\mathcal{D}}{?}$ ten cases regarded as secondary neutropenia, making a total of eighty-nine in all. Of the seventy-nine primary ones, forty-two were in females, thirty-seven 
TABle 1. Periodic neutropenia

\begin{tabular}{|c|c|c|c|c|c|c|c|c|c|c|}
\hline Author & Sex & $\begin{array}{c}\text { Age } \\
\text { (years) }\end{array}$ & $\begin{array}{l}\text { Age at } \\
\text { onset } \\
\text { (years) }\end{array}$ & $\begin{array}{l}\text { Perio- } \\
\text { dicity } \\
\text { (days) }\end{array}$ & $\begin{array}{l}\text { Mono- } \\
\text { cytosis }\end{array}$ & $\begin{array}{l}\text { Lympho- } \\
\text { cytosis }\end{array}$ & $\begin{array}{l}\text { Thrombo- } \\
\text { cyto- } \\
\text { penia }\end{array}$ & $\begin{array}{c}\text { Eosino- } \\
\text { philia }\end{array}$ & Familial & $\begin{array}{l}\text { Unusual } \\
\text { features }\end{array}$ \\
\hline $\begin{array}{l}\text { Lorre \& Denys } \\
\text { (1960) }\end{array}$ & F & 8 & $3 / 12$ & 23 & + & + & & + & & Rapid ESR \\
\hline Toro et al. (1960) & $\mathbf{M}$ & 2 & $4 / 12$ & $\begin{array}{l}19 \text { ( } 21 \text { days } \\
\text { after } \\
\text { cortisone) }\end{array}$ & + & & $\begin{array}{l}\text { Thrombo- } \\
\text { cytosis }\end{array}$ & & & $\begin{array}{l}\text { Sialorrhoea, } \\
\text { diarrhoea, seizures }\end{array}$ \\
\hline Bray (1960) & $\mathbf{F}$ & 9 & $?$ & 21 & & & & & & $\begin{array}{l}\text { Serious infections, } \\
\text { steroids ineffective }\end{array}$ \\
\hline $\begin{array}{l}\text { Gorlin \& } \\
\quad \text { Chaudry (1960) }\end{array}$ & $\mathbf{F}$ & 8 & 4 & 21 & & & & & + & \\
\hline $\begin{array}{l}\text { Malooly (by } \\
\text { letter) }\end{array}$ & $\mathbf{M}$ & 54 & 33 & 28 & $\begin{array}{l}\text { Mono- } \\
\text { cyto- } \\
\text { penia }\end{array}$ & & & & & $\begin{array}{l}\text { Prednisone } \\
\text { meliorated } \\
\text { symptoms only }\end{array}$ \\
\hline Alestig (1961) & $\mathbf{F}$ & 58 & 54 & 14 & & & & & & $\begin{array}{l}\text { Prednisone } \\
\text { meliorated } \\
\text { symptoms only. } \\
\text { Spontaneous } \\
\text { remission } 1 \text { year } \\
\text { fever } 40^{\circ} \mathrm{C}\end{array}$ \\
\hline $\begin{array}{l}\text { Telsey et al. } \\
\text { (1962) }\end{array}$ & F & 14 & $4 / 12$ & \pm 21 & & & & & & $\begin{array}{l}\text { Splenectomy and } \\
\text { steroids ineffective }\end{array}$ \\
\hline Videbaek (1962) & $\begin{array}{l}\mathbf{M} \\
\mathbf{M} \\
\mathbf{M}\end{array}$ & $\begin{array}{r}29 \\
2 \\
18\end{array}$ & $\begin{array}{c}2 \\
10 / 12 \\
1\end{array}$ & $\begin{array}{c}21 \\
21 \\
21 ; \text { later } \\
14\end{array}$ & + & & & & + & $\begin{array}{l}\text { Fever } 39^{\circ} \mathrm{C} \\
\text { Fever } 38^{\circ} \mathrm{C}\end{array}$ \\
\hline $\begin{array}{l}\text { Wade \& Stafford } \\
\text { (1963) }\end{array}$ & $\mathbf{M}$ & 38 & 32 & $21-28$ & & & & & & $\begin{array}{l}\text { Splenectomy, pred- } \\
\text { nisone relieved } \\
\text { symptoms only }\end{array}$ \\
\hline $\begin{array}{r}\text { Coutel, Morel \& } \\
\text { Thomet (1963) }\end{array}$ & $\mathbf{M}$ & 6 & 1 & \pm 21 & + & & & & & Pulm. abscess \\
\hline Smith (1964) & $\mathbf{M}$ & 20 & 6 & 14-20 & & & & & & $\begin{array}{l}\text { Hypergamma- } \\
\text { globulinaemia }\end{array}$ \\
\hline $\begin{array}{l}\text { Journal of the } \\
\text { American Medi- } \\
\text { cal Association } \\
\text { (1965) }\end{array}$ & $\mathbf{F}$ & 22 & 16 & $?$ & & & & & & $\begin{array}{l}\text { Five episodes of } \\
\text { pancreatitis }\end{array}$ \\
\hline Simonsen (1966) & $\mathbf{F}$ & 21 & 17 & \pm 21 & & $\begin{array}{l}\text { Lympho- } \\
\text { cyto- } \\
\text { penia }\end{array}$ & 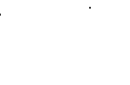 & & & $\begin{array}{l}\text { Abdominalgia, } \\
\text { arthralgia }\end{array}$ \\
\hline $\begin{array}{l}\text { Morley (1967) } \\
\text { Twenty cases }\end{array}$ & $\begin{array}{l}7 \mathrm{M} \\
13 \mathrm{~F}\end{array}$ & & $\begin{array}{l}\text { Usually } \\
\text { child- } \\
\text { hood }\end{array}$ & $15-35$ & Often & & & & 7 familial & $\begin{array}{l}\text { Periodic arthralgia } \\
\text { in three }\end{array}$ \\
\hline Felitti (by letter) & $\mathbf{F}$ & 6 & $?$ & $?$ & & & & & & Died, peritonitis \\
\hline $\begin{array}{l}\text { Waldron-Shah } \\
\text { (by letter) }\end{array}$ & $\mathbf{F}$ & 35 & 8 & 21 & + & + & & + & $\begin{array}{l}\text { Doubtful } \\
\text { in several } \\
\text { relatives }\end{array}$ & $\begin{array}{l}\text { Stethalgia, abdomi- } \\
\text { nalgia, arthralgia, } \\
\text { erythema, xero- } \\
\text { stomia, diaphoresis, } \\
\text { diarrhoea, oedema, } \\
\text { somnolence, pallor }\end{array}$ \\
\hline
\end{tabular}

in males. They began in infancy in twenty-seven and after age 60 in three. Periodicity generally ranged from 14 to 28 days, mostly 20 or 21 . Monocytosis or monocytopenia, lymphocytosis or lymphocytopenia, eosinophilia and thrombocytopenia or thrombocytosis characterized some instances. The recorded numbers depended upon whether cells were counted during episodies or in the intervals. Published reports do not always specify the timing. Serious infections occasionally ensued and seven ended fatally. Familial involvement was evident in eleven instances. In several groups, symptomless relatives were neutropenic or had recurrent oral ulcers without detected rhythm. Pregnancy suppressed, worsened or had no effect on episodes. Corticosteroids meliorated the symptoms in a few, but had slight or no effect on the cellular cycles. Splenectomy seldom was justified. As found in common with other disparate periodic disorders, synchronous fever, sialorrhea, xerostomia, exanthems, arthrosis, abdominalgia and diarrhoea occasionally occurred.

Similar to human disease, six grey Collie dogs had heritable periodic neutropenia. Three had concurrent gingival and dermal ulcers, arthralgia and 
fever. Neutropenic episodes recurred every 8-13 days averaging 10 with compensatory monocytosis (Lund, Padgett \& Ott, 1967).

\section{Complement anomaly in periodic neutropenia}

Study of my patient E.C. disclosed the inhibitor of $\mathrm{C} 1$ esterase reduced from a normal 5.6 units to $3 \cdot 6$ $\mathrm{u}$ and $4 \mathrm{u}$ in two respective episodes, and to $4 \mathrm{u}$ in an interval. His whole serum complement activity during the two episodes measured $34 \mathrm{u}$ and $58 \mathrm{u}$, and in the symptomless interval $44 \mathrm{u}$ (normal $62 \pm 19 \mathrm{u}$ ) (Reimann, Coppola \& Villegas, 1970). Splenectomy failed to help the patient. Testosterone meliorated the symptoms for a time by preventing extreme neutropenia. It induced concurrent monocytosis, and lymphocytosis and increased the granulocytic reserve as demonstrated by the pyrogen stimulation test (Brodsky, Reimann \& Dennis, 1965).

\section{Aysmptomatic and secondary periodic neutropenia}

Morley demonstrated symptomless neutropenia at intervals of 14-23 days in eight of eleven normal men from unaffected families. Similar oscillation accompanied mensis in two normal women (Morley, 1966). The behavior indicates the existence of an underlying inherent biorhythm and a feedback mechanism affecting the formation of cells. This action in genetically susceptible persons provokes disease (Reimann, 1948). In one of my patients with periodic polyserositis (Case 1, Reimann, 1948), periods of symptomless neutropenia, monocytosis and lymphocytosis occasionally recurred separately from episodes of her disease.

After the deliberate impairment of immunity, Alexander demonstrated fluctuation of antibacterial activity of neutrophils in cycles usually of 14-24 days in patients and monthly in dogs. The activity was independent of the number of neutrophils. Injury and immunosuppressive therapy adversely affected phagocytosis but did not abolish the basic cycle. As in periodic neutropenia, infection occasion- ally concurred (Alexander. Dıonigi \& Meakins, ڤ 1971). Morley \& Stohlman using cyclophosphamide reduced the number of neutrophils in dogs and 2 lowered neutropenia every 11-17 days (Morley \& Stohlman, 1970). A hypothetic feedback control was discussed in detail (Morley, 1970).

Patients with polycythemia or leukaemia and secondary periodic neutropenia listed in Table 2 all were adults. The rhythm of neutropenia ranged from $\overparen{\mathbb{D}}$ 30 to 120 days. Its amplitude probably was extended to that length by the gravity of the underlying $\mathrm{c}$ diseases or by therapy thereof. Thrombocytopenia $\vec{\circ}$ concurred in four. Episodes of neutropenia affected $\vec{\overrightarrow{ }}$ agammaglobulinemic children (Telsey, et al., 1962).

\section{Neutropenia and pancreatic disturbance}

Neutropenia and pancreatic dysfunction affected a child at 21-day intervals (Colebatch et al., 1965). In six other patients, a 'new' entity, in one instance or familial, consisted of pancreatic insufficiency, $\bullet$ anaemia, neutropenia and occasional thrombocytopenia and purpura. The tabulated data suggest $\circ$ unnoticed recurrent episodes of neutropenia (Shwachman et al., 1964). Bodian also commented $\vec{c}$ on the combination of congenital pancreatic hypo-plasia, neutropenia and thrombocytopenia (Bodian, $\vec{\varphi}$ Sheldon \& Lightwood, 1964). Fluctuation of the three factors appears in the tables of two of patients, but cell counts were too widely spaced detect regular periodicity. Elsewhere I describe periodic pancreatosis without attention to neutro-ō philic changes (Reimann, 1962).

\section{Periodicity during haemal diseases}

In a polycythemic patient, the number of neutro- $\frac{0}{3}$ phils fluctuated every 15 days, the platelets every $27 \bar{\partial}$ days, both within the normal range. A reticulocyte cycle of another patient lasted 17 days (Morley, 1969a). As noted by Morley and others, periodic 3 . neutropenia occasionally accompanies lymphoma-; toses (Morley, Baikie \& Galton, 1967) (Table 2). In

TABle 2. Secondary periodic neutropenia

\begin{tabular}{|c|c|c|c|c|c|c|c|c|}
\hline & Disease & Sex & $\begin{array}{c}\text { Age } \\
\text { (years) }\end{array}$ & $\begin{array}{l}\text { Age at } \\
\text { onset }\end{array}$ & $\begin{array}{l}\text { Perio- } \\
\text { dicity } \\
\text { (days) }\end{array}$ & $\begin{array}{l}\text { Mono- } \\
\text { cytosis }\end{array}$ & $\begin{array}{l}\text { Thrombo- } \\
\text { cyto- } \\
\text { penia }\end{array}$ & \\
\hline Morley (1969a) & Polycythemia & $\mathbf{M}$ & 68 & 8 & 15 & + & $\begin{array}{c}\stackrel{+}{27-d a y} \\
\text { cycles }\end{array}$ & $\begin{array}{l}\text { Another patient had peri- } \\
\text { odic reticulocytopenia at } \\
\text { 17-day intervals }\end{array}$ \\
\hline \multirow[t]{3}{*}{$\begin{array}{l}\text { Morley, Baikie \& Galton } \\
\text { (1967) }\end{array}$} & $\begin{array}{l}\text { Myelogenous } \\
\text { leukaemia }\end{array}$ & $\mathbf{F}$ & 42 & $?$ & $50-55$ & & + & Modified by therapy \\
\hline & $\begin{array}{l}\text { Leukaemia } \\
\text { Leukaemia }\end{array}$ & $\begin{array}{l}\mathbf{M} \\
\mathbf{F}\end{array}$ & $\begin{array}{l}45 \\
60\end{array}$ & $\begin{array}{c}? \\
57 ?\end{array}$ & $\begin{array}{c}30-35 \\
30\end{array}$ & & + & $\begin{array}{l}\text { Modified by therapy } \\
\text { Modified by therapy }\end{array}$ \\
\hline & Leukaemia & $\mathbf{M}$ & 37 & $35 ?$ & $100-120$ & & & Modified by therapy \\
\hline Kennedy (1970) & $\begin{array}{l}5 \text { patients } \\
\text { Myelogenous } \\
\text { leukaemia }\end{array}$ & & & & $30-50$ & & + & \\
\hline
\end{tabular}


Kennedy's five patients with myelogenous leukaemia treated with hydroxyurea, leucocytes and platelets fluctuated in 30-50-day cycles (Kennedy, 1970). Rhythm may be obscured by therapy or by the gravity of the primary disease. On the other hand, either therapy or the disease induces oscillation.

\section{Secondary lymphocytosis}

Lymphocytosis occasionally accompanies normal mensis (Minot, 1936). During lymphocytic leukaemia in a patient, spells of fever, polyuria and facial oedema appeared at 5-10 day intervals. Four months of observation disclosed a lymphocytelymphoblast number of about 280,000 which diminished to normal during episodes. The $2 \%$ of segmented cells diminished slightly in unison. An attack of herpes zoster temporarily lengthened the rhythm to 15 and 17 days. On one occasion, withdrawal of spinal fluid promptly increased the number of lymphocytes and averted an expected febrile episode. The event suggested central neural or neurohumoral regulation (Stacher \& Bohnel, 1958). The idea was based on the experimental demonstration of prompt leucocytosis after mechanical disturbance of the hypothalamic area. Although governed centrally, the effect presumably is mediated humorally on the marrow (Rosenow, 1951).

\section{Periodic thrombocytopenia}

Since Demmer's report, at least six primary cases have been described (Demmer, 1920). In one instance, a man had episodes of bleeding for 42 years. His platelets diminished monthly to fewer than $50,000 /$ $\mathrm{mm}^{3}$ after reduction of megakaryocytes in the marrow. The numbers of leucocytes and erythrocytes remained normal. Prednisone was ineffective (Engstrom, Lundquist \& Soderstrom, 1966). A man, aged 37, had five episodes of thrombocytopenia and bleeding, each one worse until death from cerebral haemorrhage. Episodes came at predicted 21-day intervals. Platelet counts ranged from 0 to 500,000/ $\mathrm{mm}^{3}$. Splenectomy and prednisone had failed to help (Wasastjerna, 1967).

Table 3 lists the six patients. The disorder began in middle age. Periodicity ranged from 21 to 39 days. One patient had haemolytic anaemia. One died during an episode. Spenectomy and corticosteroid therapy had no effect.

\section{Asymptomatic and secondary periodic thrombo- cytopenia}

Morley discovered a 21-35-day rhythmic oscillation in the number of platelets in normal persons. In occasional susceptible persons like these, bleeding may occur regardless of the degree of thrombocytopenia (Morley, 1969b). Rhythm may be overlooked unless serial counts are made. If these are made on patients with essential thrombocytopenic purpura, rhythmic fluctuation of platelets may become evident in some of them. Correct diagnosis obviates splenectomy which is ineffective for periodic thrombocytopenia.

Thrombocytopenia and purpura also occur in rhythm with mensis (Pohle, 1939). In a woman aged 46, episodes of epistaxis, menorrhagia and purpura recurred every 28 days for $\mathbf{8}$ years. Episodes usually coincided with mensis and also happened in the midperiod. Platelets varied in number from 10,000 to 300,000 . The marrow contained nonfunctioning megakaryocytes fluctuating in rhythm. Normal hormonal amounts remained constant. Because episodes recurred regularly after oophorectomy (Skoog, Lawrence \& Adams, 1957), prior relation to mensis may have been coincidental. In another woman, thrombocytopenic purpura happened at every other menstrual flow (Pepper, Liebowitz \&

TABLe 3. Periodic thrombocytopenia

\begin{tabular}{|c|c|c|c|c|c|c|}
\hline & Sex & $\begin{array}{c}\text { Age } \\
\text { (years) }\end{array}$ & $\begin{array}{l}\text { Age at } \\
\text { onset }\end{array}$ & $\begin{array}{l}\text { Periodicity } \\
\text { (days) }\end{array}$ & Symptoms & Comment \\
\hline Demmer (1920) & $\mathbf{M}$ & 61 & 55 & 28 & Purpura & $\begin{array}{l}\text { Irregular synchronous lympho- } \\
\text { cytosis. Death from nephritis }\end{array}$ \\
\hline Skoog et al. (1957) & $\mathbf{F}$ & 46 & 38 & 28 & $\begin{array}{l}\text { Epistaxis, menorrhagia, } \\
\text { purpura, mucosal lesions }\end{array}$ & $\begin{array}{l}\text { With and between mensis. } \\
\text { Persisted after oophorectomy }\end{array}$ \\
\hline Dameshek (by letter) & $\mathbf{F}$ & 42 & & 27 & $\begin{array}{l}\text { Episodes of haemolytic } \\
\text { anaemia, thrombocytopenic } \\
\text { purpura }\end{array}$ & $\begin{array}{l}\text { Had prior splenectomy for } \\
\text { haemolytic anaemia }\end{array}$ \\
\hline $\begin{array}{l}\text { Engstrom et al. (1966) } \\
\text { Bernard \& Caen }\end{array}$ & $\begin{array}{l}\mathbf{M} \\
\mathbf{M}\end{array}$ & $\begin{array}{l}61 \\
54\end{array}$ & $\begin{array}{l}59 \\
12\end{array}$ & $\begin{array}{c}39 \\
\text { Monthly }\end{array}$ & $\begin{array}{l}\text { Purpura } \\
\text { Buccal ulcers, subcutaneous } \\
\text { haemorrhages }\end{array}$ & $\begin{array}{l}\text { 'Absolutely regular sequence' } \\
\text { Corticosteroid and splenec- } \\
\text { tomy, no effect }\end{array}$ \\
\hline $\begin{array}{l}\text { Candura (1960) } \\
\text { Fourteen cases re- } \\
\text { lated to mensis }\end{array}$ & & & & & & \\
\hline
\end{tabular}


Lindsay, 1956). In the published case record, lower platelet counts appear without comment at about 20day intervals suggesting a circa 21-day periodicity. Candura described two cases related to mensis and cited reports of at least twelve others chiefly in Italian and German journals (Candura, 1960). These are regarded here as secondary but if included in Table 3 would make a total number exceeding twenty. More cases, no doubt, will be diagnosed when serial counts are made.

Regardless of known platelet participation, bleeding and purpura can be induced periodically in religious stigmatists presumably by wilful excitement of the autonomic neurovascular system (Agle \& Ratnoff, 1962).

\section{Periodic erythrocytic oscillation}

A 7-year-old boy had 'congenital hypoplastic anaemia and periodic erythrocytopenia' since infancy. At first, episodes came at 2-3-month intervals, later about twice yearly. The marrow during episodes showed erythrocytic aplasia. The child was well between episodes and developed normally otherwise. An infant brother died from anaemia (Gordon \& Varadi, 1962).

A man who died at age 21 from Hodgkin's disease had had numerous episodes of anaemia with increased sedimentation-rate, lymphocytopenia and fever. Two-week-long episodes alternated with about 3 weeks of relative good health. Five episodes were observed during 5 months in a hospital. Because of brisk erytnropoiesis in the marrow, his physicians regarded the periodic anaemia as of haemolytic origin (Ranløv \& Videbaeck, 1963).

Ashby observed 8-16-day cycles of haematopoesis in animals and changes in human erythrocyte numbers every 14 days (Ashby, 1948). In Morley's polycythemic patient, independent reticulocyte, neutrophil and platelet cycles indicated that normal homeostatic controls still were functional (Morley 1969a). A 14-day oscillatory rhythm of reticulocytes appeared in dogs. Bleeding and transfusion shifted the oscillatory phases (Morley \& Stohlman, 1969).

\section{Discussion}

In the past 20 years, clinical interest in life-long recurrent disorders in otherwise healthy persons has increased. Many examples have been delineated and added to those described previously. They are included in a proposed group of disparate nosologically related entities. Common to all are heritability, precise or irregular periodicity, overlapping features, menstrual suppression of episodes, resistance to therapy and similar serum-complemental defects (Reimann, 1963).

Considering the interrelation of periodic disorders, the case described to me as one of possible periodic neutropenia by Waldron-Shah (Table 1) is pertinent. The patient has constant leucopenia with periods of neutropenia every 21 days 'predictable to the day'. Other leucocytes increase reciprocally. $\stackrel{\square}{\longrightarrow}$ During episodes, the usual oral ulcers appear. But in $\overrightarrow{\overrightarrow{\vec{s}}}$ addition, there occur fever, severe abdominalgia and stethalgia, arthralgia of elbows and knees, and등 oedema of the eyelids, face, palate and hands. These $\overline{\bar{c}}$. features respectively characterize periodic poly- $\widehat{\phi}$ serositis, periodic arthrosis and periodic oedema. Myalgia, sialorrhea, xerostomia, erythema, somno- $\infty$ lence, blurred vision, diaphoresis, tachypnea, vomit- $\overrightarrow{0}$ ing and diarrhoea common to all periodic disorders $\overrightarrow{-}$ also concur at times in the episodes as autonomic ${ }_{\sigma}$ reactions. An electroencephalogram was normal. Because none of the symptoms predominate con $-\frac{0}{3}$ sistently, a basic diagnosis of periodic neutropenia with composite symptoms is appropriate.

It may be recalled that a patient with periodic ${ }_{0}$ polyserositis (Case 1, Reimann, 1948), cited above $\stackrel{6}{G}$ had occasional separate periods of neutropenia. As $\not$ indicated in Table 1, Simonsen's neutropenic 0 patient had abdominalgia and arthralgia. Some family members of Morley's group had arthralgia, $\vec{C}$ and Lorre's patient had synchronous sialorrhoea, diarrhoea and seizures. Periodic neutropenia with $\overrightarrow{0}$ pancreatic disturbance was mentioned abovi. Systemic disturbance is obvious.

Regarding periodic haemal disorders, sever⿳亠口冋. entities have emerged. According to the tables, primary periodic haemal disorders begin at any time of life, occasionally are familial, have overlapping features, resist therapy and occasionally are $\stackrel{\mathbb{Q}}{\varrho}$ fatal. Evidence of similar periodicity emerges during $\overrightarrow{\overrightarrow{0}}$ unrelated diseases. Periodicity can also be induced 3 experimentally in man and animals. Various haemal $\bar{F}$ cells oscillate in number independently or in com-? binations. When independent, specific names may be $\frac{-}{0}$ applied; for combinations, the term myelodysplasia 3 . seems apropos. Synchronous increases in numbers $\dot{\sigma}$ of certain cells may be compensatory or specific.

The immediate site of disturbance is in the marrow. 8 Why the oscillatory rhythm varies in days, weeks or months, often precisely, in different patients and for 0 different cells is unknown. Occasional temporal $D$ association with mensis may indicate either hormonal incitement or the synchronous effects of two separate biorhythms. Morley's discovery of similar $\Omega$ haemocytic cycles in asymptomatic members of $N$ afflicted families, in normal persons, and in animals $\underset{\mathrm{N}}{\mathrm{N}}$ indicates the ubiquity of the rhythm. Exaggeration $\bar{\sigma}$ of oscillation or oscillation in susceptible persons evokes periodic disease.

Alexander demonstrated depressed antibacterial $\stackrel{\mathbb{R}}{\rightarrow}$ action of neutrophils in the usual 14-24-day rhythm 0 in normal persons. At the nadir of action, infection

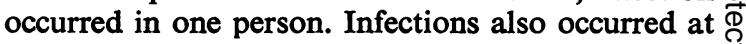


the time in burned patients and in others treated with immunosuppressive drugs. The behavior may be one variable factor favoring unexpected recurrent infections. Long biorhythms as principles of life and reactions to them are of much more clinical importance than disturbances incident to the circadian rhythm.

Concerning the ultimate cause, no demonstrable inborn-error of metabolism or endocrinal influence participates. The circadian rhythm, extraneous geophysical or cosmic influences have no bearing. Whether a complement disturbance observed in the single case of periodic neutropenia is a characteristic and relevant to the cause cannot be said without further evidence.

Theoretically, an inherent biorhythm excites the hypothalamic area, the effects of which are mediated neurally. Pertinent to the blood, Richter postulated the existence of local bioclocks or Zeitgebers in cells of the marrow (Richter, 1960). An action-phase in the stem cells of each of the haematopoetic components may synchronize independently to cause neutropenia, lymphocytopenia, thrombocytopenia, reticulocytopenia or anaemia, or these in various combinations. The bearing of the theories on the feed-back proposal (Morley, 1970) is conjectural. Does feedback control the rhythm or the reverse? Morley, King-Smith \& Stohlman (1970) discussed the matter of haemal periodicity in detail concluding that 'if many systems do show the same principles of control as does haemopoiesis, many periodic diseases may arise in similar fashion'.

\section{References}

Agle, D.P. \& Ratnoff, O.D. (1962) Purpura as a psychosomatic entity. Archives Internal Medicine, 109, 685.

Alestig, K. (1961) Cyclic agranulocytosis treated with steroids. Acta medica Scandinavica, 169, 253

Alexander, J.W., Dionigi, R. \& Meakins, J.L. (1971) Periodic variation in the antibacterial function of human neutrophils and its relation to sepsis. Annals of Surgery. (In press.)

AsHBY, W. (1948) The span of life of the red blood cell. A résumé. Blood, 3, 486.

Bernard, J. \& Caen, J. (1962) Purpura thrombopénique et mégacariocytopénia cycliques mensuels. Nouvelle Review Française de Hématologie, 2, 387.

Bodian, M., Sheldon, W. \& Lightwood, R. (1964) Congenital hypoplasia of the exocrine pancreas. Acta Paediatrica, 53, 282.

BRAY, P.T. (1960) Cyclical neutropenia. Proceedings of the Royal Society of Medicine, 53, 1057.

Brodsky, I., ReimanN, H.A. \& Dennis, L.H. (1965) Treatment of cyclic neutropenia with testosterone. American Journal of Medicine, 38, 802.

Candura, M. (1960) Su due casi di porpora intermittente mestruale piastrinopenica. Haematologia, 45, 457.

Colebatch, J.H., Anderson, C.M., Simons, M.J. \& Burke, V. (1965) Neutropenia and pancreatic disorders. Lancet, ii, 496.

Coutel, Y., Morel, H. \& Thomet, G. (1963) Neutropénie cyclique chez un enfant de 6 ans. Nouvelle Review Francaise deHématologie, $3,482$.
Demmer, T. (1920) Morbus maculosis Werlhofii in Regelmässigen vier Wochenliche Schuben bei einen 60 Jährigen Mann nebst Untersuchungen über Blutplättchen. Folia haematologica, 26, 74.

Engstrom, K., LundQuist, A. \& Soderstrom, N. (1966) Periodic thrombocytopenia or tidal platelet disgenesis in a man. Scandinavian Journal of Haematology, 3, 290.

GORDON, R.R. \& VARADI, S. (1962) Congenital hypoplastic anemia with periodic erythroblastopenia. Lancet, i, 296.

Gorlin, R.J. \& ChaudRY, A.P. (1960) The oral manifestations in chronic myelogenous leukemia during hydroxyurea therapy. Blood, 35, 751.

Journal of the American Medical Association (1965) Cyclic neutropenia. 193, 752.

KENNEDY, B.J. (1970) Cyclic leukocyte oscillations in chronic myelogenous leukemia during hydroxyurea therapy. Blood, 35, 751.

LORRE, J. \& Denys, P. (1960) Contribution à l'étude des neutropénies cycliques. Acta Paediatrica Belgica, 14, 178.

Lund, J.E., Padgetr, G.A. \& OTT, R.L. (1967) Cyclic neutropenia in grey Collie dogs. Blood, 29, 452.

Minot, G.R. (1936) Purpura hemorrhagica and lymphocytosis. Acute type and intermittent menstrual type. American Journal of the Medical Sciences, 192, 445.

MORLEY, A.A. (1966) A neutrophil cycle in healthy individuals. Lancet, ii, 1220.

MORLEY, A. (1969a) Blood-cell cycles in polycythaemia vera. Australasian Annals of Medicine, 18, 124.

MORLEY, A.A. (1969b) A platelet cycle in normal individuals. Australasian Annals of Medicine, 18, 127.

Morley, A.A. (1970) Periodic diseases, physiological rhythms and feedback control-a hypothesis. Australasian Annals of Medicine, 19, 244.

Morley, A.A., Baikie, A.G. \& Galton, D.A.G. (1967) Cyclic leukocytosis as evidence for retention of normal homeostatic control in chronic granulocytic leukaemia. Lancet, ii, 1320.

Morley, A.A., CAREw, J.P. \& BaIKIE, A.G. (1967) Familial cyclic neutropenia. British Journal of Haematology, 13, 719.

Morley, A., King-Smith, A. \& Stohlman, F. The oscillatory nature of hemopoesis. In: Hemopoetic Cellular Proliferation (Ed. by F. Stohlman) pp. 3-14. Grune \& Stratton, Inc., New York.

Morley, A. \& Stohlman, F. (1969) Erythropoesis in the dog. The periodic nature of the steady state. Science, 165 , 1025.

Morley, A. \& Stohlman, F. (1970) Cyclophosphamideinduced cyclical neutropenia. An animal model of a human periodic disease. New England Journal of Medicine, 282, 643.

Pepper, H., Liebowitz, D. \& Lindsay, S. (1956) Cyclical thrombocytopenic purpura related to the menstrual cycle. Archives of Pathology, 61, 1.

PoHLE, S.F. (1939) The blood platelet count in relation to the menstrual cycle in normal women. American Journal of the Medical Sciences, 197, 40.

Ranløv, P. \& VidebaeK, A. (1963) Cyclic haemolytic anaemia synchronous with Pel-Ebstein fever in a case of Hodgkin's disease. Acta medica Scandinavica, 174, 583.

Reimann, H.A. (1948) Periodic diseases. Journal of the American Medical Association, 136, 239.

Reimann, H.A. (1962) Periodic pancreatosis. Journal of the Indian Medical Profession, 9, 4189.

Reimann, H.A. (1963) Periodic Diseases, pp. 1-189. Blackwell Scientific Publications, Oxford, and F. A. Davis, Co., Philadelphia.

Reimann, H.A., \& de Berardinis, C.T. (1949) Periodic (cyclic) neutropenia, an entity. A collection of 16 cases. Blood, 4, 1109. 
Reimann, H.A., Coppola, E.D. \& Villegas, G.R. (1970). Complement system defects in periodic diseases. Annals of Internal Medicine, 73, 737.

RICHTER C. (1960) Biological clocks in medicine and psychiatry: Shock-phase hypothesis. Proceedings of the National Academy of Sciences, 46, 1506.

RosenOW, G. (1951) The nervous humoral regulation of the leukocytes. Acta haematologica, 5, 1.

Shwachman, H., Diamond, L.K., Oski, F.A. \& Shaw, K-T. (1964) The syndrome of pancreatic insufficiency and bone marrow dysfunction. Journal of Pediatrics, 65, 645.

Simonsen, E. (1966) Cyklisk agranulocytose. Nordisk Medicine, 76, 1061.

Skoog, W.A., LAWkenCe, J.S. \& Adams, W.S. (1957) A metabolic study of a patient with idiopathic cyclical thrombocytopenic purpura. Blood, 12, 844.
Smith, J.F. (1964) Cyclic neutropenia. Oral Surgery, Oral Medicine and Oral Pathology, 18, 312.

STACHER, A. \& BöHNEL, J. (1958) Eigenartiges Krankheitsbild einer zyklisch leukämischaleukämischen Lymphomatose. $\subset$ Wiener Klinische Wochenschrift, 70, 158.

Telsey, B., Beube, F.E., Zegarelli, E.V. \& Kutscher, A.H. (1962) Oral manifestations of cyclical neutropenia. Oral Surgery, Oral Medicine and Oral Pathology, 15, 540.

TORO, A.H., Allande, R.S. \& MeSA, S.A. (1960) Neutropenia ciclica. Reporte de un caso. Boletin Medical del $\frac{\omega}{\sqrt{\sigma}}$ Hospital Infantil, 17, 215.

VIDEBAEK, A. (1962) Cyclic neutropenia. Report of three cases. Acta medica Scandinavica, 172, 715.

WADE, A.B. \& STAFFORD, J.L. (1963) Cyclical neutropenia Oral Surgery, Oral Medicine, and Oral Pathology, 16, 1443.

WASASTJERNA, C. (1967) Cyclic thrombocytopenia of acute type. Scandinavian Journal of Haematology, 4, 380. 